\title{
CoViD-19: Weekly Mortality Cycle and Sunday Protective Phenomenon.
}

\author{
Dr. Mikhail Teppone.
}

\author{
Dr. Mikhail Teppone, \\ Medical Director, Nano City Holdings Berhad, \\ No. 1, Jalan Sungai Jeluh 32/192, \\ Shah Alam, 40460, Selangor, Malaysia. \\ Email: mikhail.teppone@gmail.com
}

September 21, 2020

\section{Abstract.}

Background. The Weekly Mortality Cycle among CoViD-19 patients has been studied.

Methods. Mortality data obtained from the 'Worldometer' website were analyzed with a comparison of absolute values, percentages, and p-value.

Results. For patients suffering from CoViD-19, the most favorable or the safest days of the week were Sundays and Mondays.

Conclusion. The weekly cycle with decreased mortality on Sundays and Mondays is a unique phenomenon observed among victims of CoViD-19. Presumably the decreased mortality on certain days of the week related to the optimized therapeutic protocols used on the "safest days".

Keywords. CoViD-19, Mortality, Weekly Cycle, Weekly Mortality Cycle.

Abbreviation. HLM - is a ratio between a number of deaths on the day with the highest mortality and a number of deaths on the day with the lowest mortality.

\section{Introduction.}

The CoViD-19 Pandemic is the first documented coronavirus pandemic in history, ${ }^{1}$ that will remain in the human memory as one of the famous disasters in this century. There were a new virus and information about it which were spreading throughout the world speedily. At the present time Google offers more than 6 billion results per query for "CoViD-19".2

Based on the analysis of pandemic outbreak one can define that the first patient presumably infected with SARS-CoV-2, appeared in China around October or November 2019, at least 1-2 months prior to the story on seafood market in Wuhan became popular. ${ }^{3}$ It can be concluded that epidemic was not originated by the animal-to-human transmission in Wuhan market, but the market was a temporary place allowing virus transmission from the infected patients to the new victims. ${ }^{4}$ According to the estimation based on the susceptible-infected removed model for the dynamics of the epidemic waves, the CoViD-19 pandemic probably began in August 2019.5 
Diagnostic kits to identify SARS-CoV-2 infected patients became available beginning of January $2020 .{ }^{3}$ Since then, statistics related to the new disease became available for analysis. ${ }^{6}$

In the first report provided by a group of experts from Imperial College London, there were 41 confirmed cases with 2 deaths; the estimated number of infected people was $1,723,{ }^{7}$ (the estimated mortality rate was around $-0.12 \%$ ). In the second report provided by the same group of experts, there were 440 confirmed cases with 9 deaths, and the estimated number of infected people was around $4000,{ }^{8}$ (the estimated mortality rate was around - $0.23 \%$ ). According to the subsequent studies, the mortality rate among SARS-CoV-2 infected people is less than $1 \%,{ }^{9}$ and can vary around $0.3-0.5 \% .{ }^{10}$

Collection of the date dealing with the current pandemic should be done with great care otherwise coronavirus mortality overestimation can lead to wrong decisions. ${ }^{11}$

\section{Challenges of CoViD-19 Pandemic.}

From the first days of the pandemic outbreak, it became clear that disease-oriented approach in medicine, which had been used successfully to cope with the task of stabilizing the symptoms encountered in the case of chronic diseases, had limited value when the new acute infectious disease emerged.

It is well known that acute disease is not a stable and constant pathological condition, but it has several phases, and each of them requires different medication and care. Therefore, it is not logical to look for a drug for the treatment of CoViD-19 in general, but it is reasonable to look for groups of medications that could be effective to treat various phases of this disease.

Due to the fact that CoViD-19 is a new disease, world public health care had to start new clinical trials to find medicines that could be safe and effective in treating patients with CoViD-19 and comorbidities. As a result, all people infected with SARS-CoV-2 have been automatically converted into participants for the most extensive clinical trials in the history of mankind. Efficacy of these trials can be analyzed on the basis of global and local statistics.

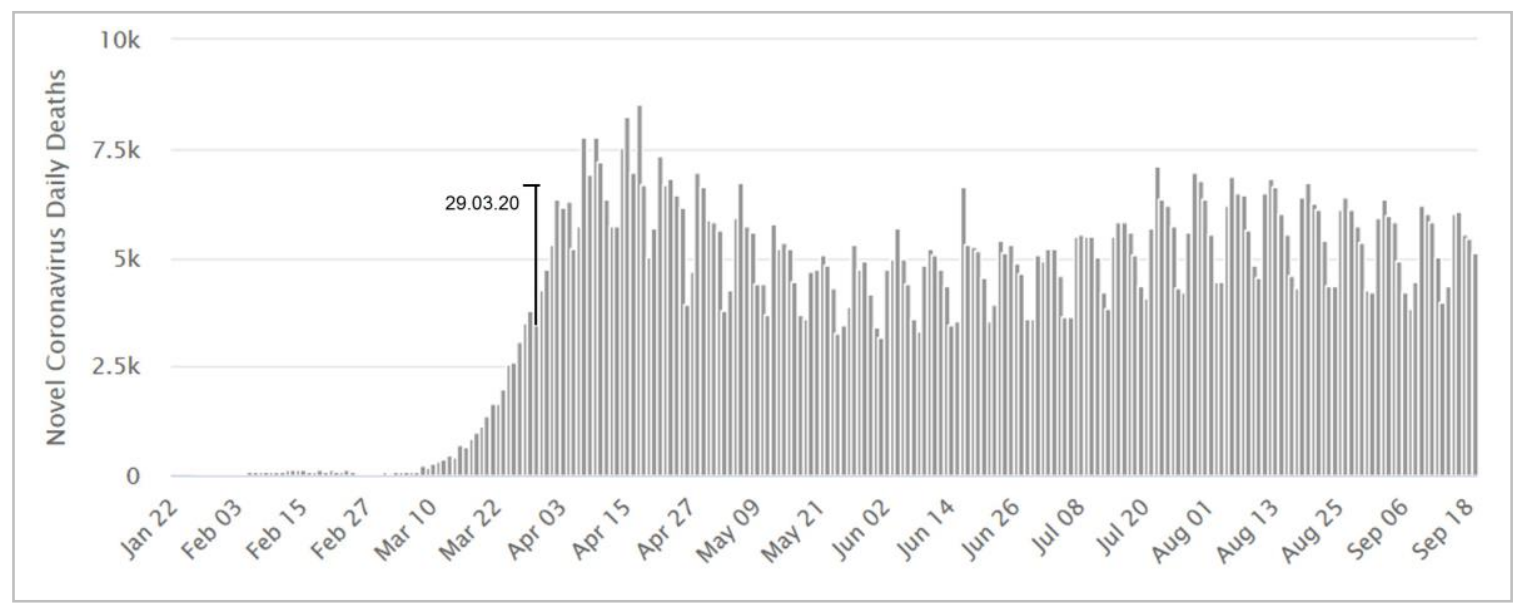

Figure 1. Daily New Deaths due to CoViD-19 worldwide (screenshot, on September 20, 2020). 


\section{A Global Weekly Mortality Cycle related to CoViD-19.}

Background: On the CoViD-19 mortality statistics presented on the 'Worldometer' website, ${ }^{6}$ a weekly cycle of decreased mortality on Sundays and Mondays is evident (Fig. 1). This cycle can vary in different countries, ${ }^{12}$ but the main trend is decreased mortality towards weekends. ${ }^{13}$

Objective: To study weekly mortality cycle among CoViD-19 patients.

2.1. Methods: Since July 6, 2020, data from 'Worldometer' website were collected every 5-6 days in the form of numbers and screenshots. The date when information was collected is given in the text. Data processing was divided into two parts: the first was calculating mortality on certain days of the week worldwide; the second was calculating mortality on certain days of the week in various countries.

Table 1. Global Mortality Due to CoViD-19 from January 24 to August 5, 2020 [collected on August 6, 2020].

\begin{tabular}{|c|c|c|c|c|c|c|c|c|}
\hline week, \# & Sun & Mon & Tue & Wed & Thu & Fri & Sat & \\
\hline & & & & & & $* 16$ & 15 & $* \operatorname{Jan} 24$ \\
\hline 1 & 24 & 26 & 26 & 38 & 43 & 46 & $* 45$ & $*$ Feb 1 \\
\hline 2 & 58 & 64 & 66 & 73 & 73 & 86 & 89 & \\
\hline 3 & 97 & 108 & 97 & 146 & 122 & 143 & 143 & \\
\hline 4 & 106 & 98 & 136 & 117 & 121 & 113 & 100 & \\
\hline 5 & 158 & 81 & 64 & 37 & 58 & 65 & 54 & \\
\hline 6 & $* 73$ & 67 & 85 & 83 & 102 & 106 & 105 & $* \operatorname{Mar} 1$ \\
\hline 7 & 228 & 197 & 274 & 330 & 353 & 448 & 414 & \\
\hline 8 & 691 & 645 & 819 & 986 & 1101 & 1384 & 1648 & \\
\hline 9 & 1648 & 1937 & 2495 & 2593 & 2966 & 3478 & 3711 & \\
\hline 10 & 3381 & 4185 & 4749 & $* 5201$ & 6304 & 6018 & 6156 & $*$ Apr 1 \\
\hline 11 & 5080 & 5652 & 7905 & 6804 & 7686 & 7417 & 6339 & \\
\hline 12 & 5682 & 5731 & 7452 & 8201 & 7045 & 8494 & 6703 & \\
\hline 13 & 4994 & 5580 & 7237 & 6668 & 6783 & 6424 & 6200 & \\
\hline 14 & 3855 & 4537 & 6775 & 6650 & 5854 & $* 5709$ & 5337 & * May 1 \\
\hline 15 & 3601 & 4124 & 5862 & 6876 & 5642 & 5531 & 4332 & \\
\hline 16 & 4065 & 3521 & 5572 & 5263 & 5318 & 5061 & 4404 & \\
\hline 17 & 3687 & 3520 & 4628 & 4673 & 5008 & 4698 & 4232 & \\
\hline 18 & 3225 & 3370 & 3838 & 5378 & 4733 & 4972 & 4189 & \\
\hline 19 & 3329 & $* 3123$ & 4728 & 4989 & 5626 & 4968 & 4343 & $*$ Jun 1 \\
\hline 20 & 3575 & 3229 & 4824 & 5233 & 5085 & 4703 & 4353 & \\
\hline 21 & 3384 & 3496 & 6658 & 5306 & 5252 & 5212 & 4563 & \\
\hline 22 & 3445 & 3904 & 5517 & 5146 & 5266 & 4928 & 4677 & \\
\hline 23 & 3561 & 3517 & 5147 & *4949 & 5260 & 5300 & 4626 & $*$ Jul 1 \\
\hline 24 & 3720 & 3670 & 5628 & 5671 & 5523 & 5537 & 5131 & \\
\hline 25 & 4254 & 3891 & 5592 & 5917 & 5879 & 5681 & 5125 & \\
\hline 26 & 4423 & 4122 & 5838 & 7180 & 6368 & 6243 & 5741 & \\
\hline 27 & 4354 & 4234 & 5682 & 7036 & 6457 & 6468 & $* 5664$ & $*$ Aug 1 \\
\hline 28 & 4483 & 4377 & 6303 & 6838 & & & & \\
\hline Sum, $n$ & 74,698 & 76,629 & 107,694 & 111,544 & 110,028 & 109,233 & 98,424 & $\Sigma=688,250$ \\
\hline Mean & 2,767 & 2,838 & 3,989 & 4,131 & 4,075 & 4,046 & 3,645 & \\
\hline SD & $\pm 1,858$ & $\pm 1,936$ & $\pm 2,732$ & $\pm 2,785$ & $\pm 2,674$ & $\pm 2,651$ & $\pm 2,329$ & \\
\hline$\%$ & 10.85 & 11.13 & 15.65 & 16.21 & 15.98 & 15.87 & 14.30 & HLM $=1.47$ \\
\hline
\end{tabular}


There were comparisons between the total mortality on certain days of the week in absolute values and percentages. There was an additional criteria used, that was a ratio between a number of deaths on the day with the highest mortality and a number of deaths on the day with the lowest mortality, that can be termed as high/low mortality ratio or HLM. In the initial study 27 weeks were analysed (26.01.20-01.08.20).

Results: During the mentioned weeks there have been a total of 688,250 deaths from CoViD-19, worldwide (Table 1). 74,698 (10.85\%) patients died on Sundays, 76,629 (11.13\%) on Mondays, 107,694 (15.65\%) on Tuesdays, 111,544 (16.21\%) on Wednesdays, 110,028 (15.98\%) on Thursdays, 109,233 (15.87\%) on Fridays, and 98,424 (14.30\%) on Saturdays.

The highest daily mortality was on Wednesday and the lowest daily mortality was on Sunday. The HLM ratio, calculated as 111,544 divided by 74,698 , was 1.493 .

2.2. Methods: For the further study only 18 weeks were analysed (29.03.20 - 01.08.20). By the limitation of the time frame, unstable deviations of death numbers related to the initial exponential growth phase were eliminated partly (Fig. 1).

Results: there were a total of 656,362 deaths from CoViD-19, worldwide (Table 2): 71,615 (10.91\%) patients died on Sundays, 73,406 (11.18\%) on Mondays, 103,632 (15.79\%) on Tuesdays, 107,141 (16.32\%) on Wednesdays, 105,089 (16.01\%) on Thursdays, 103,364 (15.75\%) on Fridays, and 92,115 (14.04\%) on Saturdays. The HLM ratio was 1.496.

Table 2. Global Mortality Due to CoViD-19 on Various Days of the Week (29.03.20 - 01.08.20).

\begin{tabular}{|l|r|r|r|r|r|r|r|r|}
\hline & Total & Sun & Mon & Tue & Wed & Thu & Fri & Sat \\
\hline Sum, $\mathrm{n}$ & 656,362 & 71,615 & 73,406 & 103,632 & 107,141 & 105,089 & 103,364 & 92,115 \\
\hline Mean & & 3,979 & 4,078 & 5,757 & 5,952 & 5,838 & 5,742 & 5,118 \\
\hline SD & & \pm 695 & \pm 817 & \pm 1084 & \pm 998 & \pm 789 & \pm 993 & \pm 829 \\
\hline$\%$ & $100 \%$ & 10.91 & 11.18 & 15.79 & 16.32 & 16.01 & 15.75 & 14.04 \\
\hline
\end{tabular}

2.3. Methods: The comparison of the global daily mortality between various days of the week done with the calculation of the $p$-value. If $p$-value was 0.001 or less, for example, 0.0005 , or 0.00005 , it was presented as $\mathrm{p}<0.001$. The same approach was used in the further studies. 18 weeks were analysed (29.03.20-01.08.20).

Results: The global daily mortality on Sundays or Mondays was less than global daily mortality on Tuesdays, Wednesdays, Thursdays, Fridays and Saturdays $(\mathrm{p}<0.001)$.

Discussion: If the low mortality on Sundays was related to the registration of the deceased, one could assume that all cases not recorded on Sundays must be added to the death cases on Mondays, and as a result, the number of deaths on Mondays must be not less than on other days of the week. In reality, the number of deaths on Mondays was almost as low as on Sundays. 
Conclusion: For patients suffering from CoViD-19 worldwide, the most favorable or safest days of the week were Sundays and Mondays (Fig. 2).

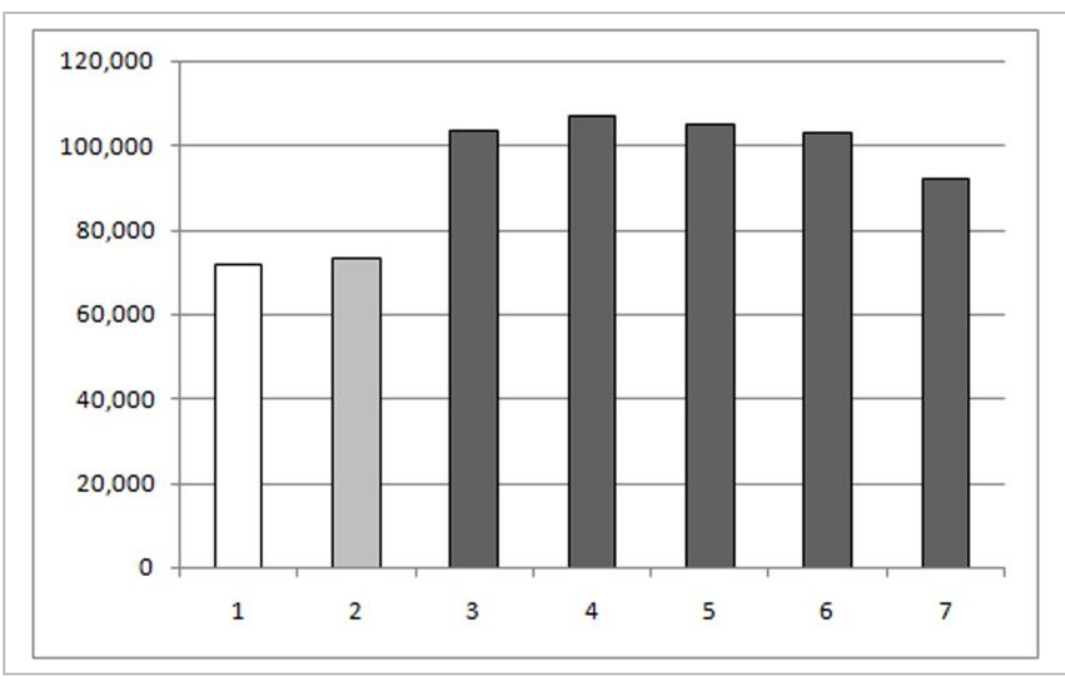

Figure 2. Global Mortality Due to CoViD-19 on Various Days of the Week (29.03.20 - 01.08.20).

1. Sunday (white), 2. Monday (grey), 3. Tuesday, 4. Wednesday, 5. Thursday, 6. Friday, 7. Saturday (all black).

\section{The Weekly Mortality Cycle related to CoViD-19 in Various Countries.}

Background: The global trend that may be termed the "Weekly Mortality Cycle" with more or less certainty, has been revealed in various countries including Brazil, Chile, Germany, Mexico, Russia, the United Kingdom and the United States of America.

Table 3: Mortality in various days of the week in Brazil, Chile, Mexico, Germany, Russia, USA and UK.*

\begin{tabular}{|c|c|c|c|c|c|c|c|c|}
\hline Countries: & $\begin{array}{l}\text { Total } \\
\text { HLM }\end{array}$ & Sun & Mon & Tue & Wed & Thu & Fri & Sat \\
\hline $\begin{array}{l}\text { United States: } \\
\text { 29.03-01.08 }\end{array}$ & $\begin{array}{l}155,115 \\
1.99\end{array}$ & $\begin{array}{l}13,825 \\
8.91 \%\end{array}$ & $\begin{array}{l}16,024 \\
10.33 \%\end{array}$ & $\begin{array}{l}27,178 \\
17.52 \%\end{array}$ & $\begin{array}{l}27,525 \\
17.74 \%\end{array}$ & $\begin{array}{l}25,638 \\
16.53 \%\end{array}$ & $\begin{array}{l}24,302 \\
15.67 \%\end{array}$ & $\begin{array}{l}20,623 \\
13.3 \%\end{array}$ \\
\hline $\begin{array}{l}\text { Brazil: } \\
\\
26.04-01.08 \\
\end{array}$ & $\begin{array}{l}8^{89,571} \\
2.09 \\
\end{array}$ & $\begin{array}{l}7,398 \\
8.26 \% \\
\end{array}$ & $\begin{array}{r}9,153 \\
10.22 \% \\
\end{array}$ & $\begin{array}{l}15,378 \\
17.17 \% \\
\end{array}$ & $\begin{array}{r}15,161 \\
16.93 \% \\
\end{array}$ & $\begin{array}{l}15,498 \\
17.30 \% \\
\end{array}$ & $\begin{array}{l}14,423 \\
16.1 \% \\
\end{array}$ & $\begin{array}{r}12,560 \\
14.02 \% \\
\end{array}$ \\
\hline $\begin{array}{r}\text { United Kingdom: } \\
29.03-01.08\end{array}$ & $\begin{array}{l}44,670 \\
2.06\end{array}$ & $\begin{array}{l}4,041 \\
9.05 \%\end{array}$ & $\begin{array}{l}3,646 \\
8.16 \%\end{array}$ & $\begin{array}{l}8,333 \\
18.65 \%\end{array}$ & $\begin{array}{l}7,598 \\
17.01 \%\end{array}$ & $\begin{array}{l}6,834 \\
15.30 \%\end{array}$ & $\begin{array}{l}7,723 \\
17.29 \%\end{array}$ & $\begin{array}{l}6,495 \\
14.54 \%\end{array}$ \\
\hline $\begin{array}{l}\text { Mexico: } \\
19.04-01.08\end{array}$ & $\begin{array}{l}{ }^{46,142} \\
2.31\end{array}$ & $\begin{array}{l}5,425 \\
11.76 \% \\
\end{array}$ & $\begin{array}{l}3,704 \\
8.03 \% \\
\end{array}$ & $\begin{array}{l}4,598 \\
9.96 \% \\
\end{array}$ & $\begin{array}{r}8,441 \\
18.29 \% \\
\end{array}$ & $\begin{array}{r}8,548 \\
18.52 \% \\
\end{array}$ & $\begin{array}{l}7,847 \\
17.01 \% \\
\end{array}$ & $\begin{array}{r}7,579 \\
16.43 \% \\
\end{array}$ \\
\hline $\begin{array}{l}\text { Russia: } \\
26.04-01.08\end{array}$ & $\begin{array}{l}13,377 \\
1.57\end{array}$ & $\begin{array}{r}1,499 \\
11.20 \% \\
\end{array}$ & $\begin{array}{r}1,414 \\
10.57 \% \\
\end{array}$ & $\begin{array}{l}2,093 \\
15.64 \% \\
\end{array}$ & $\begin{array}{r}2,204 \\
16.48 \% \\
\end{array}$ & $\begin{array}{l}1,966 \\
14.70 \% \\
\end{array}$ & $\begin{array}{r}2,224 \\
16.63 \% \\
\end{array}$ & $\begin{array}{r}1,977 \\
14.78 \% \\
\end{array}$ \\
\hline $17.05-01.08$ & $2.70^{8,496}$ & $\begin{array}{l}1,354 \\
15.94 \%\end{array}$ & $8.46 \%$ & $6.50 \%^{552}$ & $\begin{array}{r}1,360 \\
16.01 \%\end{array}$ & $\begin{array}{l}1,490 \\
17.54 \%\end{array}$ & $\begin{array}{l}1,448 \\
17.04 \%\end{array}$ & $\begin{array}{l}1,573 \\
18.51 \%\end{array}$ \\
\hline $\begin{array}{l}\text { Germany: } \\
29.03-23.05\end{array}$ & $2.18^{7,933}$ & $8.80 \%$ & $\begin{array}{r}1,165 \\
14.70 \%\end{array}$ & $\begin{array}{r}1,337 \\
16.85 \%\end{array}$ & $\begin{array}{r}1,521 \\
19.17 \%\end{array}$ & $\begin{array}{r}1,321 \\
16.65 \%\end{array}$ & $\begin{array}{r}1,129 \\
14.23 \%\end{array}$ & $9.60 \%$ \\
\hline
\end{tabular}

As it was presented above, the lowest worldwide mortality due to CoViD-19 was on Sundays and Mondays. In various countries days of the week with the lowest mortality can vary nevertheless they either belong to the weekend or they are near the weekend.

* Data base was collected on August 10, 2020. 
Due to the fact that the time of CoViD-19 outbreak varied in the different countries, the analysed weeks varied too. All analysed periods started on a Sunday and ended on a Saturday.

Methods: The data on mortality from CoViD-19 in different countries were taken from the site 'Worldometer'. ${ }^{14}$ A comparison of the total mortality on certain days of the week in absolute values and percentages in various countries was carried out (Table 3).

Results: A comparison of the total mortality on certain days of the week has revealed that in the analysed countries daily mortality on Sundays or Mondays was less than on other days of the week, excluding Chile, where the lowest mortality due to CoDiD-19 was on Tuesdays. The highest HLM ratio was in Chile (2.70), the lowest one was in Russia (1.57).

Conclusion: For patients suffering from CoViD-19, the safest days of the week were mostly Sundays or Mondays.

\section{4. "Sunday Protective Phenomenon" and "Monday Protective Phenomenon".}

There are several combinations of days with the lowest mortality, but the most common are Sundays and Mondays. These may be termed "Sunday Protective Phenomenon" (Fig. 3) and "Monday Protective Phenomenon" (Fig. 4) respectively.

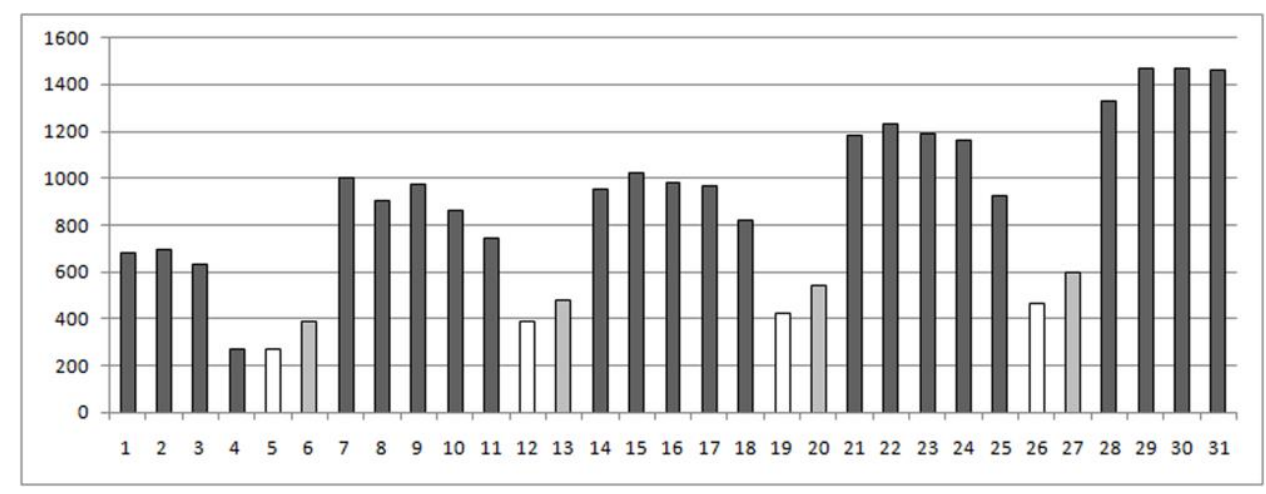

Figure 3. Daily New Deaths due to CoViD-19 in the United States of America, in July 2020.

Sunday is white color; Monday is grey; Tuesday, Wednesday, Thursday, Friday and Saturday all are black.

In some countries analysis of the daily mortality in July (2020), revealed a stable weekly cycle with the one and the same day of the lowest mortality being either Sunday (Fig. 3) or Monday (Fig. 4); but in others, the day of the lowest mortality varied being both Sunday or Monday (Fig. 5).

4.1. "Sunday Protective Phenomenon" discovered in the United States, Brazil and Germany.

Methods: The comparison of the daily mortality between various days of the week in various countries done with the calculation of the $p$-value.

The United States of America (29.03-01.08): On Sundays, the daily mortality was less than on Tuesdays, Wednesdays ( $\mathrm{p}<0.001)$, Thursdays, Fridays ( $\mathrm{p}<0.005)$, and Saturdays $(\mathrm{p}<0.05)$. On Mondays, 
the daily mortality was less than on Wednesdays ( $p<0.005)$, Tuesdays, Thursdays $(p<0.01)$, and Fridays $(\mathrm{p}<0.05)$.

Brazil (26.04-01.08): On Sundays, the daily mortality was less than on Tuesdays, Wednesdays, Thursdays, Fridays, Saturdays $(\mathrm{p}<0.001)$ and Mondays $(\mathrm{p}<0.05)$. On Mondays, the daily mortality was less than on Tuesdays, Wednesdays, Thursdays, and Fridays $(\mathrm{p}<0.001)$, and Saturdays $(\mathrm{p}<0.05)$.

Germany (29.03-23.05): On Sundays, the daily mortality was less than on Mondays, Tuesdays, Wednesdays and Thursdays $(\mathrm{p}<0.05)$. On Saturdays, the daily mortality was less than on Wednesdays $(\mathrm{p}<0.05)$.

4.2. "Monday Protective Phenomenon" discovered in the United Kingdom, Mexico and Russia.

Methods: The comparison of the daily mortality between various days of the week in various countries done with the calculation of the $p$-value.

The United Kingdom (29.03-01.08): On Mondays, the daily mortality was less than on Tuesdays, Wednesdays, and Fridays ( $\mathrm{p}<0.05)$. On Sundays, the daily mortality was less than on Tuesdays and Wednesdays $(\mathrm{p}<0.05)$.

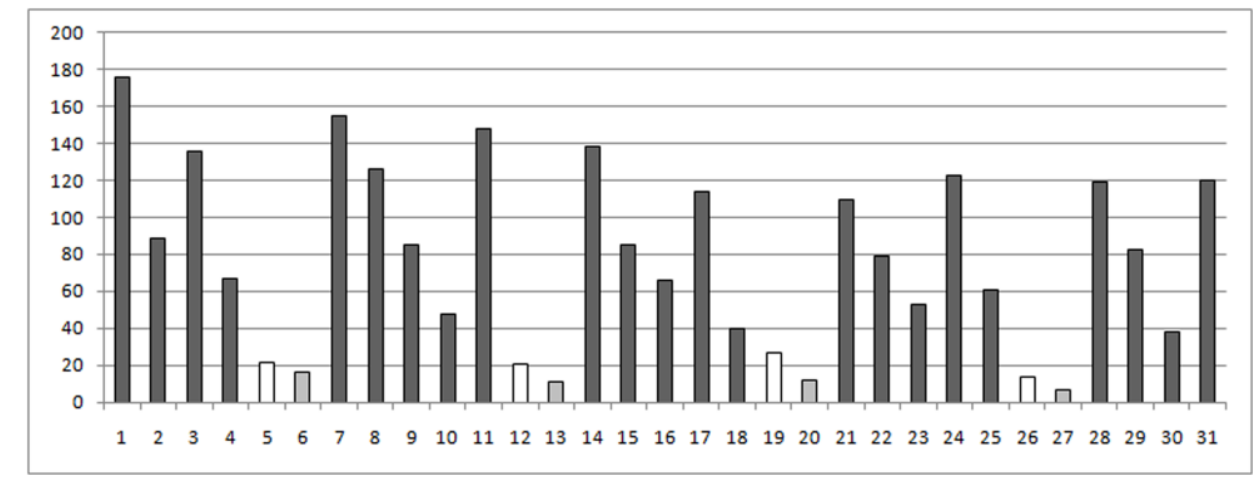

Figure 4. Daily New Death due to CoViD-19 in the United Kingdom, in July 2020:

Sunday is white color; Monday is grey; Tuesday, Wednesday, Thursday, Friday and Saturday all are black.

Mexico (19.04-01.08): On Mondays, the daily mortality was less than on Wednesdays, Thursdays, Fridays and Saturdays $(\mathrm{p}<0.005)$. On Tuesdays, the daily mortality was less than on Wednesdays, Thursdays, Fridays and Saturdays $(\mathrm{p}<0.05)$. On Sundays, the daily mortality was less than on Wednesdays and Thursdays $(\mathrm{p}<0.05)$.

Russia (26.04-01.08): On Mondays, the daily mortality was less than on Tuesdays, Wednesdays, Fridays ( $\mathrm{p}<0.001)$, Thursdays $(\mathrm{p}<0.005)$, and Saturdays $(\mathrm{p}<0.05)$. On Sundays, the daily mortality was less than on Wednesdays, Fridays ( $p<0.001)$, Tuesdays ( $\mathrm{p}<0.005)$, Thursdays, and Saturdays $(\mathrm{p}<0.05)$.

Chile (10.05-01.08): On Tuesdays, the daily mortality was less than on Sundays, Thursdays, Fridays, Saturdays $(\mathrm{p}<0.01)$ and Wednesdays $(\mathrm{p}<0.05)$. On Mondays, the daily mortality was less than on Sundays, Thursdays, Fridays and Saturdays $(\mathrm{p}<0.05)$. 
Conclusion: The weekly mortality cycle was discovered in Brazil, Chile, Germany, Mexico, Russia, in the United Kingdom and United States of America. In majority of these countries, for patients suffering from CoViD-19, the safest days of the week were either Sundays or Mondays. In Chile, the safest days of the week were Mondays and Tuesdays (Table 3).

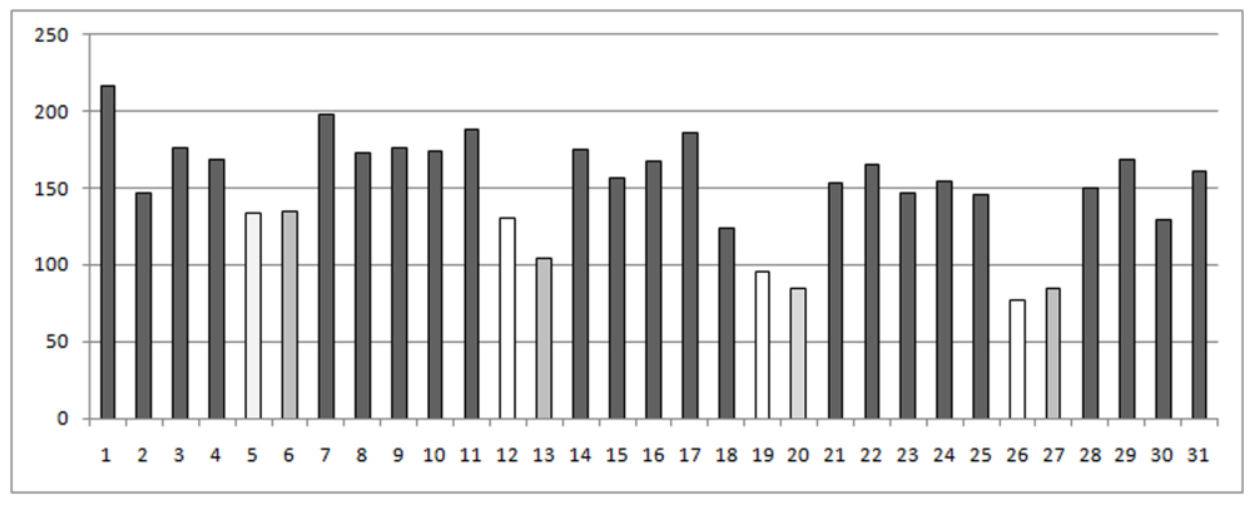

Figure 5. Daily New Deaths due to CoViD-19 in Russia, in July 2020:

Sunday is white color; Monday is grey; Tuesday, Wednesday, Thursday, Friday and Saturday all are black.

\section{The Weekly Mortality Cycle in the States of the United States with the highest mortality.}

Background: Due to the fact that the United States had the highest numbers of death related to CoViD-19, ${ }^{14}$ the weekly mortality cycle was analysed in the states of Arizona, California, Connecticut, Georgia, Florida, Illinois, Louisiana, Massachusetts, Michigan, New Jersey, New York, Ohio, Pennsylvania, and Texas.*

Table 4: Total Daily Mortality on Various Days of the Week in the certain States of the USA (29.03-01.08).

\begin{tabular}{|c|c|c|c|c|c|c|c|c|}
\hline States: & $\begin{array}{l}\text { Total } \\
\text { HLM ratio }\end{array}$ & Sun & Mon & Tue & Wed & Thu & Fri & Sat \\
\hline United States: & $1.99^{155,115}$ & $\begin{array}{l}13,825 \\
8.91 \%\end{array}$ & $\begin{array}{l}16,024 \\
10.33 \%\end{array}$ & $\begin{array}{l}27,178 \\
17.52 \%\end{array}$ & $\begin{array}{l}27,525 \\
17.74 \%\end{array}$ & $\begin{array}{l}25,638 \\
16.53 \%\end{array}$ & $\begin{array}{r}24,302 \\
15.67 \%\end{array}$ & $\begin{array}{l}20,623 \\
13.3 \%\end{array}$ \\
\hline New York & $1.26^{31,358}$ & $\begin{array}{r}4,462 \\
14.23 \% \\
\end{array}$ & $\begin{array}{r}4,351 \\
13.88 \% \\
\end{array}$ & $\begin{array}{c}5,067 \\
16.16 \% \\
\end{array}$ & $\begin{array}{c}5,034 \\
16.05 \% \\
\end{array}$ & $\begin{array}{r}4,140 \\
13.20 \% \\
\end{array}$ & $\begin{array}{r}4,298 \\
13.71 \% \\
\end{array}$ & $\begin{array}{r}4,006 \\
12.77 \% \\
\end{array}$ \\
\hline New Jersey & $2.67^{15,896}$ & $\begin{array}{l}1,342 \\
8.44 \%\end{array}$ & $\begin{array}{c}1,121 \\
7.05 \%\end{array}$ & $\begin{array}{c}2,836 \\
17.84 \%\end{array}$ & $\begin{array}{l}2,945 \\
18.53 \%\end{array}$ & $\begin{array}{c}2,995 \\
18.84 \% \\
\end{array}$ & $\begin{array}{r}2,398 \\
15.09 \%\end{array}$ & $\begin{array}{r}2,259 \\
14.21 \%\end{array}$ \\
\hline Pennsylvania & 7,246 & $5.715^{414}$ & $7.15 \%{ }^{518}$ & $\begin{array}{r}1,391 \\
19.20 \%\end{array}$ & $\begin{array}{l}1,545 \\
21.32 \%\end{array}$ & $\begin{array}{l}1,376 \\
18.99 \%\end{array}$ & $\begin{array}{r}1,142 \\
15.76 \%\end{array}$ & $\begin{array}{r}860 \\
11.87 \%\end{array}$ \\
\hline Texas & 7,234 & $6.07 \%$ & $8.65 \%{ }^{626}$ & $\begin{array}{l}1,117 \\
15.44 \% \\
\end{array}$ & $\begin{array}{r}1,388 \\
19.19 \%\end{array}$ & $\begin{array}{r}1,365 \\
18.87 \%\end{array}$ & $\begin{array}{c}1,299 \\
17.96 \%\end{array}$ & $\begin{array}{r}1,000 \\
13.82 \%\end{array}$ \\
\hline Georgia & 3,746 & $3.68 \%{ }^{138}$ & $\begin{array}{r}581 \\
15.51 \%\end{array}$ & $\begin{array}{r}810 \\
21.62 \%\end{array}$ & $\begin{array}{r}\text { 671 } \\
17.91 \%\end{array}$ & $\begin{array}{r}571 \\
15.25 \%\end{array}$ & $\begin{array}{r}649 \\
17.33 \%\end{array}$ & $8.70 \%{ }^{326}$ \\
\hline Arizona & 3,716 & $5.57 \%$ & $2.4 \%$ & $\begin{array}{r}737 \\
19.83 \%\end{array}$ & $\begin{array}{r}672 \\
18.08 \%\end{array}$ & $\begin{array}{l}673 \\
18.11 \%\end{array}$ & $\begin{array}{r}629 \\
16.93 \%\end{array}$ & $\begin{array}{r}709 \\
19.08 \%\end{array}$ \\
\hline
\end{tabular}

Methods: There were comparisons between the total mortality on certain days of the week in absolute values, percentages and a calculation of HLM ratio (Table 4). A comparison of daily mortality between certain days of the week with the calculation of the $p$-value has been done too.

* Data base was collected on August 10, 2020. 
Results: Significant differences in mortality due to CoViD-19 between various days of the week were revealed in the states of Arizona, California, Florida, Georgia, Illinois, Louisiana, Michigan, New Jersey, Ohio, Pennsylvania and Texas $(\mathrm{p}<0.05 \div \mathrm{p}<0.001)$.

Conclusion: The weekly mortality cycle was discovered in the United States as a whole country and in the certain states. In majority of states, for patients suffering from CoViD-19, the safest days of the week were either Sundays or Mondays.

\section{Countries with the Unconfirmed Weekly Mortality Cycle.}

In Belgium, Canada, China, Colombia, France, India, Iran, Italy, Netherlands, Peru, South Africa, Spain, Sweden and some other countries, the difference in total mortality between certain days of the week was not significant $(\mathrm{p}>0.05) .{ }^{*}$ Nevertheless, in the majority of countries examined, the days with the lowest mortality were either Sundays (Table 5) or Mondays (Table 6)

Table 5: Daily Mortality due to COVID-19 was the lowest on Sundays.

\begin{tabular}{|c|c|c|c|c|c|c|c|c|}
\hline $\begin{array}{l}\text { Country: } \\
\text { Dates: }\end{array}$ & HLM $^{\text {Total }}$ & Sun & Mon & Tue & Wed & Thu & Fri & Sat \\
\hline $\begin{array}{l}\text { Italy } \\
\quad 08.03-23.05\end{array}$ & $\begin{array}{l}32,441 \\
1.24^{3} \\
\end{array}$ & $\begin{array}{l}4,035 \\
12.44 \% \\
\end{array}$ & $\begin{array}{l}4,314 \\
13.30 \% \\
\end{array}$ & $\begin{array}{l}4,778 \\
14.73 \% \\
\end{array}$ & $\begin{array}{r}4,678 \\
14.42 \%\end{array}$ & $\begin{array}{l}4,657 \\
14.35 \%\end{array}$ & $\begin{array}{c}4,993 \\
15.39 \%\end{array}$ & $15.37 \%$ \\
\hline $\begin{array}{l}\text { Spain } \\
15.03-13.06\end{array}$ & $\begin{array}{l}28,088 \\
.15^{2} \\
\end{array}$ & $\begin{array}{r}3,797 \\
13.52 \% \\
\end{array}$ & $\begin{array}{r}3,911 \\
13.92 \% \\
\end{array}$ & $\begin{array}{r}4,003 \\
14.25 \% \\
\end{array}$ & $\begin{array}{c}4,378 \\
15.59 \% \\
\end{array}$ & $\begin{array}{r}4,035 \\
14.37 \% \\
\end{array}$ & $\begin{array}{r}3,986 \\
14.19 \% \\
\end{array}$ & $\begin{array}{r}3,978 \\
14.16 \% \\
\end{array}$ \\
\hline $\begin{array}{l}\text { France } \\
\quad 22.03-16.05\end{array}$ & $2.21^{27,063}$ & $\begin{array}{l}2,325 \\
8.59 \%\end{array}$ & $\begin{array}{c}3,564 \\
13.17 \%\end{array}$ & $\begin{array}{c}4,494 \\
16.61 \%\end{array}$ & $\begin{array}{l}4,051 \\
14.97 \%\end{array}$ & $\begin{array}{c}5,148 \\
19.02 \%\end{array}$ & $\begin{array}{c}4,121 \\
15.23 \%\end{array}$ & $\begin{array}{r}3,360 \\
12.41 \%\end{array}$ \\
\hline $\begin{array}{l}\text { Peru } \\
\quad 29.03-01.08\end{array}$ & $1.13^{19,387}$ & $\begin{array}{c}2,593 \\
13.37 \%\end{array}$ & $\begin{array}{l}2,626 \\
13.54 \%\end{array}$ & $\begin{array}{r}2,770 \\
14.29 \%\end{array}$ & $\begin{array}{r}2,825 \\
14.57 \%\end{array}$ & $\begin{array}{r}2,847 \\
14.69 \%\end{array}$ & $\begin{array}{r}2,795 \\
14.42 \%\end{array}$ & $\begin{array}{r}2,931 \\
15.12 \%\end{array}$ \\
\hline $\begin{array}{l}\text { Iran } \\
01.03-01.08\end{array}$ & $\begin{array}{l}16,976 \\
1.09^{16,6}\end{array}$ & $\begin{array}{r}2,333 \\
13.74 \%\end{array}$ & $\begin{array}{r}2,425 \\
14.29 \%\end{array}$ & $\begin{array}{r}2,451 \\
14.44 \%\end{array}$ & $\begin{array}{r}2,458 \\
14.48 \%\end{array}$ & $\begin{array}{r}2,538 \\
14.95 \%\end{array}$ & $\begin{array}{r}2,365 \\
13.93 \%\end{array}$ & $\begin{array}{r}2,406 \\
14.17 \%\end{array}$ \\
\hline $\begin{array}{l}\text { South Africa } \\
17.05-01.08\end{array}$ & $1.68^{7,509}$ & $9.91 \%{ }^{744}$ & $\begin{array}{r}1,042 \\
13.87 \%\end{array}$ & $\begin{array}{c}1,248 \\
16.62 \%\end{array}$ & $\begin{array}{c}1,020 \\
13.58 \%\end{array}$ & $\begin{array}{r}1,232 \\
16.41 \%\end{array}$ & $\begin{array}{r}1,160 \\
15.45 \%\end{array}$ & $\begin{array}{r}1,063 \\
14.16 \%\end{array}$ \\
\hline
\end{tabular}

Table 6: Daily Mortality due to COVID-19 was the lowest on Mondays.

\begin{tabular}{|c|c|c|c|c|c|c|c|c|}
\hline $\begin{array}{r}\text { Country: } \\
\text { Dates: }\end{array}$ & $\begin{array}{l}\text { Total }^{\text {Tol }} \\
\text { HLM }\end{array}$ & Sun & Mon & Tue & Wed & Thu & Fri & Sat \\
\hline $\begin{array}{l}\text { India } \\
\quad 10.05-01.08\end{array}$ & $\begin{array}{l}3^{33,641} \\
1.27^{-1}\end{array}$ & $\begin{array}{l}4,348 \\
12.92 \%\end{array}$ & $\begin{array}{l}4,197 \\
12.48 \%\end{array}$ & $\begin{array}{l}4,739 \\
14.09 \%\end{array}$ & $\begin{array}{l}5,312 \\
15.79 \%\end{array}$ & $14.6 \%$ & $\begin{array}{r}5,10 \\
15.17 \%\end{array}$ & $\begin{array}{r}5,0 \\
14.95 \%\end{array}$ \\
\hline $\begin{array}{l}\text { Colombia } \\
12.04-01.08\end{array}$ & $1.46^{10,230}$ & $\begin{array}{l}1,343 \\
13.13 \%\end{array}$ & $\begin{array}{l}1,164 \\
11.38 \%\end{array}$ & $\begin{array}{l}1,356 \\
13.25 \%\end{array}$ & $\begin{array}{l}1,429 \\
13.97 \%\end{array}$ & $\begin{array}{c}1,694 \\
16.56 \%\end{array}$ & $\begin{array}{l}1,698 \\
16.60 \%\end{array}$ & $\begin{array}{l}1,546 \\
15.11 \%\end{array}$ \\
\hline $\begin{array}{l}\text { Belgium } \\
22.03-13.06 \\
\end{array}$ & $1.48^{9,047}$ & $\begin{array}{r}1,161 \\
12.84 \% \\
\end{array}$ & $\begin{array}{r}1,038 \\
11.47 \% \\
\end{array}$ & $\begin{array}{r}1,178 \\
13.02 \% \\
\end{array}$ & $\begin{array}{c}1,539 \\
17.01 \% \\
\end{array}$ & $\begin{array}{r}1,426 \\
15.76 \% \\
\end{array}$ & $\begin{array}{l}1,480 \\
16.36 \% \\
\end{array}$ & $\begin{array}{r}1,225 \\
13.54 \% \\
\end{array}$ \\
\hline $\begin{array}{l}\text { Canada } \\
12.04-20.06\end{array}$ & $1.52^{7,615}$ & $\begin{array}{l}1.65 \% \\
887\end{array}$ & $\begin{array}{l}1.61 \% \\
884\end{array}$ & $\begin{array}{l}1117 \\
14.67 \%\end{array}$ & $\begin{array}{l}1158 \\
15.20 \%\end{array}$ & $\begin{array}{l}1344 \\
17.65 \%\end{array}$ & $\begin{array}{l}1095 \\
14.38 \%\end{array}$ & $\begin{array}{l}1130 \\
14.84 \%\end{array}$ \\
\hline $\begin{array}{l}\text { Netherlands } \\
15.03-20.06\end{array}$ & $2.04^{5,815}$ & $11.02 \%$ & $8.39 \%$ & $17.1 \%$ & $16.66 \%$ & $16.36 \%$ & $15.37 \%$ & $15.10 \%$ \\
\hline $\begin{array}{l}\text { China } \\
\quad 26.01-14.03\end{array}$ & $1.20^{3143}$ & $15.81 \%$ & $13.21 \%$ & $\begin{array}{l}{ }^{436} \\
13.87 \%\end{array}$ & $\begin{array}{l}{ }^{442} \\
14.06 \%\end{array}$ & $\begin{array}{l}{ }^{436} \\
13.87 \%\end{array}$ & $\begin{array}{r}{ }^{472} \\
15.02 \%\end{array}$ & $14.16 \%$ \\
\hline
\end{tabular}

* Data base was collected on August 10, 2020. 


\section{Revision of some numbers dealing with mortality due to CoViD-19.}

In several countries after revision of death record related to CoViD-19, some amount of the fatal cases were added, and this fact can be recognized as a sharp spike of deaths in the daily mortality chart.

Sudden increase of death number happened in China on April 17, 2020, when 1,290 new fatal cases were added (Fig. 6). ${ }^{15}$ The local authorities provided the following explanation: "The revisions were made in accordance with related laws and regulations, as well as the principle of being responsible for history, the people and the deceased". ${ }^{16}$

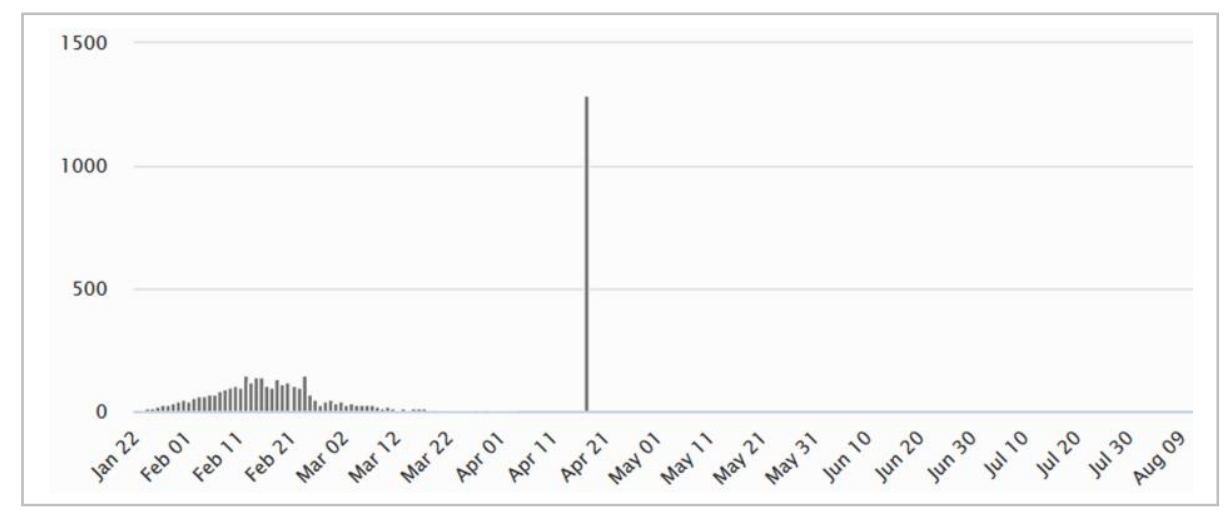

Figure 6. Daily New Death due to CoViD-19 in China [screenshot, on August 12, 2020]. Sudden increase of death number in China on April 17, 2020.

Similar corrections happened in Canada on May 31, 2020, when 222 new fatal cases were added, ${ }^{17}$ in Chile on June 7, 2020, when new 653 fatal cases were added, ${ }^{18}$ and in India on June 16, 2020, when new 2006 fatal cases were added. ${ }^{19}$ In all these cases to calculate weekly mortality cycle an average daily mortality of the affected week was applied.

There was also an opposite correction that took place in France: a number of CoViD-19 victims was decreased by 217 cases on May 19, 2020. ${ }^{20}$

\section{Updating Global Mortality Data and Weekly Mortality Cycle related to CoViD-19.}

Background: During the current observation death numbers on the 'Worldometer' website related to the whole world and to the various countries were updating constantly.

Objective: To study if updating and correction of the mortality data affects the global weekly mortality cycle related to CoViD-19.

8.1. Method: In order to know if the correction of the data for the past days affects the results of the current study, new data were collected on September 20, 2020 (Table 7).

There were comparisons between the total mortality on certain days of the week in absolute values and percentages, calculation of HLM ratio, and the comparison of the daily mortality between various days of the week with the calculation of the $p$-value. 34 weeks were analysed (26.01.20-19.09.20). 
Table 7. Global Mortality Due to CoViD-19 (26.01.20-19.09.20) [data were collected on September 20, 2020].

\begin{tabular}{|c|c|c|c|c|c|c|c|c|}
\hline week, \# & Sun & Mon & Tue & Wed & Thu & Fri & Sat & Comments \\
\hline & & & & & & $* 16$ & 15 & $*$ Jan 24 \\
\hline 1 & 24 & 26 & 26 & 38 & 43 & 46 & $* 45$ & * Feb 1 \\
\hline 2 & 58 & 64 & 66 & 73 & 73 & 86 & 89 & \\
\hline 3 & 97 & 108 & 97 & 146 & 122 & 143 & 143 & \\
\hline 4 & 106 & 98 & 136 & 117 & 121 & 113 & 100 & \\
\hline 5 & 158 & 81 & 64 & 37 & 58 & 65 & 54 & \\
\hline 6 & $* 73$ & 67 & 85 & 83 & 102 & 106 & 106 & $*$ Mar 1 \\
\hline 7 & 228 & 197 & 275 & 329 & 357 & 451 & 418 & \\
\hline 8 & 697 & 647 & 831 & 994 & 1116 & 1398 & 1658 & \\
\hline 9 & 1678 & 1970 & 2540 & 2607 & 3084 & 3521 & 3785 & \\
\hline 10 & 3454 & 4255 & 4738 & $* 5301$ & 6346 & 6149 & 6287 & * Apr 1 \\
\hline 11 & 5224 & 5722 & 7788 & 6898 & 7782 & 7216 & 6364 & \\
\hline 12 & 5753 & 5747 & 7530 & 8244 & 6983 & 8513 & 6669 & \\
\hline 13 & 5019 & 5696 & 7341 & 6661 & 6824 & 6459 & 6171 & \\
\hline 14 & 3911 & 4705 & 6973 & 6631 & 5886 & $* 5842$ & 5629 & * May 1 \\
\hline 15 & 3774 & 4285 & 5924 & 6742 & 5735 & 5586 & 4394 & \\
\hline 16 & 4411 & 3676 & 5759 & 5229 & 5339 & 5211 & 4447 & \\
\hline 17 & 3679 & 3585 & 4697 & 4726 & 5092 & 4843 & 4304 & \\
\hline 18 & 3286 & 3466 & 3875 & 5319 & 4761 & 4924 & 4177 & \\
\hline 19 & 3393 & *3196 & 4751 & 4977 & 5664 & 4969 & 4390 & $*$ Jun 1 \\
\hline 20 & 3621 & 3212 & 4815 & 5225 & 5067 & 4724 & 4351 & \\
\hline 21 & 3449 & 3564 & 6626 & 5298 & 5280 & 5166 & 4546 & \\
\hline 22 & 3536 & 3950 & 5397 & 5118 & 5306 & 4902 & 4660 & \\
\hline 23 & 3615 & 3619 & 5077 & $* 4936$ & 5221 & 5212 & 4595 & $*$ Jul 1 \\
\hline 24 & 3667 & 3655 & 5495 & 5546 & 5474 & 5494 & 5031 & \\
\hline 25 & 4226 & 3850 & 5519 & 5833 & 5828 & 5592 & 5071 & \\
\hline 26 & 4367 & 4076 & 5710 & 7132 & 6351 & 6185 & 5714 & \\
\hline 27 & 4324 & 4199 & 5578 & 6959 & 6784 & 6366 & $* 5527$ & $*$ Aug 1 \\
\hline 28 & 4462 & 4442 & 6219 & 6886 & 6482 & 6463 & 5639 & \\
\hline 29 & 4850 & 4529 & 6506 & 6843 & 6617 & 6029 & 5522 & \\
\hline 30 & 4589 & 4327 & 6377 & 6748 & 6257 & 6128 & 5409 & \\
\hline 31 & 4349 & 4370 & 6102 & 6395 & 6106 & 5748 & 5370 & \\
\hline 32 & 4252 & 4232 & $* 5925$ & 6352 & 5978 & 5840 & 4916 & $*$ Sep 1 \\
\hline 33 & 4210 & 3850 & 4466 & 6230 & 5998 & 5816 & 5028 & \\
\hline 34 & 3961 & 4381 & 6000 & 6085 & 5579 & 5460 & $* 5142$ & * Sep 19 \\
\hline Total, $\mathrm{n}$ & 106,501 & 107,847 & 149,308 & 156,738 & 153,816 & 150,766 & 135,751 & $\Sigma=960,727$ \\
\hline Mean & 3132 & 3172 & 4391 & 4610 & 4524 & 4434 & 3993 & \\
\hline SD & \pm 1798 & \pm 1841 & \pm 2571 & \pm 2654 & \pm 2536 & \pm 2474 & \pm 2180 & \\
\hline$\%$ & 11.09 & 11.23 & 15.54 & 16.31 & 16.01 & 15.69 & 14.13 & HLM $=1.47$ \\
\hline
\end{tabular}

Results: There were a total of 960,727 deaths from CoViD-19, worldwide. 106,501 (11.09\%) patients died on Sundays, 107,847 (11.23\%) on Mondays, 149,308 (15.54\%) on Tuesdays, 156,738 (16.31\%) on Wednesdays, 153,816 (16.01\%) on Thursdays, 150,766 (15.69\%) on Fridays, and 135,751 (14.13\%) on Saturdays (Table 7). The HLM ratio between Wednesday and Sunday was 1.47.

The comparison of the global daily mortality between various days of the week has revealed that global daily mortality on Sundays or Mondays was less than global daily mortality on Tuesdays, Wednesdays, Thursdays and Fridays ( $p<0.05)$. If to analyse only the last 25 weeks $(29.03-19.09 .20)$, global daily mortality on Sundays or Mondays would be less than global daily mortality on Tuesdays, Wednesdays, Thursdays, Fridays and Saturdays with the higher significance $(p<0.0001)$. 
Conclusion: For patients suffering from CoViD-19 worldwide, the safest days of the week were Sundays and Mondays (Fig 7). Updating global mortality data didn't affect results of the study.

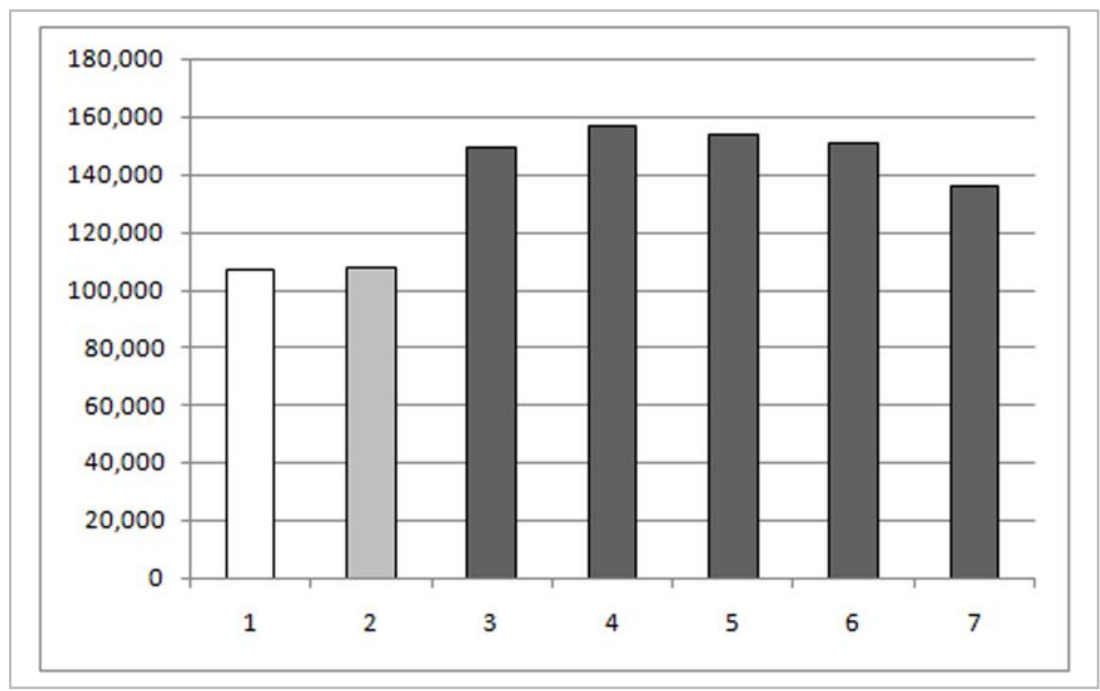

Figure 7. Global Mortality Due to CoViD-19 on Various Days of the Week (26.01.20 - 19.09.20).

1. Sunday (white), 2. Monday (grey), 3. Tuesday, 4. Wednesday, 5. Thursday, 6. Friday, 7. Saturday (all black).

8.2. Method: In order to know how update of the database affects the absolute values of the total global mortality and mortality on the various days of the week, a comparison of death numbers for the first 23 weeks (26.01.20 - 04.07.20), obtained at the different dates, has been done (Table 8).

Table 8. Global Mortality Due to CoViD-19 on Various Days of the Week (26.01.20 - 04.07.20).

There are absolute values, $\pm \Delta$, and HLM ratio. Data were obtained on different dates.

\begin{tabular}{|r|r|r|r|r|r|r|r|r|r|r|}
\hline Date & Total & $\pm \Delta$ & Sun & Mon & Tue & Wed & Thu & Fri & Sat & HLM \\
\hline 06.07 & 532,817 & n/a & 57,351 & 60,200 & 84,380 & 85,075 & 85,151 & 84,617 & 76,043 & 1.485 \\
\hline 12.07 & 532,972 & +155 & 57,360 & 60,208 & 84,401 & 85,093 & 85,181 & 84,641 & 76,088 & 1.485 \\
\hline 02.08 & 536,657 & +3685 & 57,872 & 60,643 & 84,891 & 85,679 & 85,674 & 85,226 & 76,672 & 1.480 \\
\hline 06.08 & 537,221 & +564 & 57,947 & 60,712 & 84,954 & 85,740 & 85,801 & 85,304 & 76,763 & 1.481 \\
\hline 17.08 & 539,314 & +2657 & 58,575 & 61,464 & 85,213 & 85,703 & 86,085 & 85,385 & 76,889 & 1.470 \\
\hline 27.08 & 538,730 & -584 & 58,719 & 61,708 & 84,941 & 85,420 & 86,050 & 84,985 & 76,907 & 1.465 \\
\hline 03.09 & 538,718 & -12 & 58,719 & 61,708 & 84,941 & 85,420 & 86,038 & 84,985 & 76,907 & 1.465 \\
\hline 07.09 & 541,679 & +2961 & 59,242 & 61,935 & 85,405 & 85,723 & 86,357 & 85,641 & 77,376 & 1.458 \\
\hline 09.09 & 541,679 & 0 & 59,242 & 61,935 & 85,405 & 85,723 & 86,357 & 85,641 & 77,376 & 1.458 \\
\hline 15.09 & 541,679 & 0 & 59,242 & 61,935 & 85,405 & 85,723 & 86,357 & 85,641 & 77,376 & 1.458 \\
\hline 18.09 & 541,709 & +30 & 59,244 & 61,936 & 85,411 & 85,729 & 86,362 & 85,645 & 77,382 & 1.458 \\
\hline 20.09 & 541,709 & 0 & 59,244 & 61,936 & 85,411 & 85,729 & 86,362 & 85,645 & 77,382 & 1.458 \\
\hline
\end{tabular}

Results: During the current study the total numbers of deaths related to the time frame between January 26 and July 4, 2020, were not stable. There was a fluctuation of the death numbers in the various days of the week, nevertheless the lowest numbers of deaths were on Sunday and the 
highest numbers of deaths were mostly on Thursday. A ratio between the death numbers on Thursday and Sunday decreased from 1.485, on July 12, to 1.458 , on September 7 .

8.3. Method: In order to know how update of the database affects the absolute values of the total global mortality and mortality on the various days of the week, a comparison of death numbers for other 18 weeks (29.03.20 - 01.08.20), obtained at the different dates, has been done (Table 9).

Table 9. Global Mortality Due to CoViD-19 on Various Days of the Week (29.03.20 - 01.08.20).

There are absolute values, $\pm \Delta$, and HLM ratio. Data were obtained on different dates.

\begin{tabular}{|r|r|r|r|r|r|r|r|r|r|r|}
\hline Date & Total & $\pm \Delta$ & Sun & Mon & Tue & Wed & Thu & Fri & Sat & HLM \\
\hline 02.08 & 655,799 & n/a & 71,540 & 73,337 & 103,569 & 107,080 & 104,963 & 103,286 & 92,024 & 1.497 \\
\hline 06.08 & 656,362 & +563 & 71,615 & 73,406 & 103,632 & 107,141 & 105,089 & 103,364 & 92,115 & 1.496 \\
\hline 17.08 & 655,904 & -458 & 72,038 & 73,964 & 103,294 & 106,701 & 105,038 & 103,032 & 91,837 & 1.481 \\
\hline 27.08 & 654,940 & -964 & 72,086 & 74,127 & 102,928 & 106,335 & 105,270 & 102,532 & 91,662 & 1.475 \\
\hline 03.09 & 654,917 & -23 & 72,084 & 74,127 & 102,929 & 106,334 & 105,255 & 102,528 & 91,660 & 1.475 \\
\hline 07.09 & 658,879 & +3962 & 72,707 & 74,454 & 103,579 & 106,765 & 105,714 & 103,343 & 92,317 & 1.469 \\
\hline 09.09 & 658,879 & 0 & 72,707 & 74,454 & 103,579 & 106,765 & 105,714 & 103,343 & 92,317 & 1.469 \\
\hline 15.09 & 658,879 & 0 & 72,707 & 74,454 & 103,579 & 106,765 & 105,714 & 103,343 & 92,317 & 1.469 \\
\hline 18.09 & 658,938 & +59 & 72,709 & 74,458 & 103,593 & 106,775 & 105,723 & 103,353 & 92,327 & 1.469 \\
\hline 20.09 & 658,938 & 0 & 72,709 & 74,458 & 103,593 & 106,775 & 105,723 & 103,353 & 92,327 & 1.469 \\
\hline
\end{tabular}

Results: During the current study the total numbers of deaths related to the time frame between March 29 and August 1, 2020, were not stable. There was a fluctuation of the death numbers in the various days of the week, nevertheless the lowest numbers of death were on Sunday and the highest numbers of death were on Wednesday. A ratio between the death numbers on Wednesday and Sunday decreased from 1.497, on August 2, to 1.469, on September 7, 2020.

Conclusion: The fluctuation of the total mortality due to CoViD-19 and mortality on the various days of the week didn't affect the Weekly Mortality Cycle in general. Nevertheless additional study is required to know a reason for decrease and increase of the death numbers related to the past dates.

\section{Updating Global Mortality Data and Weekly Mortality Cycle in various countries.}

Background: During the current observation death numbers on the 'Worldometer' website were updating constantly. In some countries mortality data related to the past were fairly stable, in others, the correction occurred weekly or even every 2-3 days: either up or down.

Objective: To study if the correction of the data for the days related to the past affects the weekly mortality cycle in the countries which have been already analysed in the sections \# 3, 4, 6 .

Methods: New data were collected on September 10, 2020 (Tables \# 9-11) and a comparison of the total daily mortality on the certain days of the week in absolute values and percentages in various 
countries was carried out. Then a comparison of the new results with the results obtained on August 10, 2020 (Tables \# 4-6) was done. The difference in the total death numbers presented as $+/-\Delta$.

Table 9: Mortality in various days of the week in Brazil, Chile, Mexico, Germany, Russia, USA and UK (10.09.20).

\begin{tabular}{|c|c|c|c|c|c|c|c|c|}
\hline Countries: & $\begin{array}{l}\text { Total } \\
+/-\Delta\end{array}$ & Sun & Mon & Tue & Wed & Thu & Fri & Sat \\
\hline United States: & 155,399 & 13,827 & 16,028 & 27,180 & 27,525 & 26,015 & 24,289 & 20,535 \\
\hline 29.0 & +284 & $8.90 \%$ & $10.31 \%$ & $17.49 \%$ & $17.71 \%$ & $16.74 \%$ & $15.63 \%$ & $13.22 \%$ \\
\hline $\begin{array}{l}\text { Brazil: } \\
\quad 26.04-01.08\end{array}$ & 89,571 & $\begin{array}{l}7,398 \\
8.26 \%\end{array}$ & $\begin{array}{l}9,153 \\
10.22 \%\end{array}$ & $\begin{array}{l}15,378 \\
17.17 \%\end{array}$ & $\begin{array}{c}15,161 \\
16.93 \%\end{array}$ & $\begin{array}{c}15,498 \\
17.30 \%\end{array}$ & $\begin{array}{c}14,423 \\
16.1 \%\end{array}$ & $\begin{array}{c}12,560 \\
14.02 \%\end{array}$ \\
\hline $\begin{array}{c}\text { United Kingdom: } \\
\text { 29.03-01.08 }\end{array}$ & $\begin{array}{r}39,745 \\
-4925\end{array}$ & $\begin{array}{r}3,737 \\
9.40 \%\end{array}$ & $\begin{array}{r}3,524 \\
8.87 \%\end{array}$ & $\begin{array}{r}7,187 \\
18.08 \%\end{array}$ & $\begin{array}{r}6,745 \\
16.97 \%\end{array}$ & $\begin{array}{l}6,147 \\
15.47 \%\end{array}$ & $\begin{array}{r}6,726 \\
16.92 \%\end{array}$ & $\begin{array}{l}5,679 \\
14.29 \%\end{array}$ \\
\hline $\begin{array}{l}\text { Mexico: } \\
19.04-01.08\end{array}$ & $0^{46,142}$ & $\begin{array}{l}5,425 \\
11.76 \%\end{array}$ & $\begin{array}{l}3,704 \\
8.03 \%\end{array}$ & $\begin{array}{l}4,598 \\
9.96 \%\end{array}$ & $\begin{array}{r}8,441 \\
18.29 \%\end{array}$ & $\begin{array}{c}8,548 \\
18.52 \%\end{array}$ & $\begin{array}{r}7,847 \\
17.01 \%\end{array}$ & $\begin{array}{l}7,579 \\
16.43 \%\end{array}$ \\
\hline $\begin{array}{l}\text { Russia: } \\
\text { 26.04-01.08 }\end{array}$ & 13,377 & $\begin{array}{r}1,499 \\
11.20 \%\end{array}$ & $\begin{array}{c}1,414 \\
10.57 \%\end{array}$ & $\begin{array}{l}2,093 \\
15.64 \%\end{array}$ & $\begin{array}{r}2,204 \\
16.48 \%\end{array}$ & $\begin{array}{c}1,966 \\
14.70 \%\end{array}$ & $\begin{array}{r}2,224 \\
16.63 \%\end{array}$ & $\begin{array}{c}1,977 \\
14.78 \%\end{array}$ \\
\hline 17.05-01.08 & 8,496 & $\begin{array}{l}1,354 \\
15.94 \%\end{array}$ & $8.46 \%{ }^{719}$ & $6.50 \%{ }^{552}$ & $\begin{array}{r}1,360 \\
16.01 \%\end{array}$ & $\begin{array}{l}1,490 \\
17.54 \% \\
\end{array}$ & $\begin{array}{c}1,448 \\
17.04 \%\end{array}$ & $\begin{array}{l}1,573 \\
18.51 \% \\
\end{array}$ \\
\hline $\begin{array}{l}\text { Germany: } \\
29.03-23.05\end{array}$ & 7,933 & $8.80 \%{ }^{698}$ & $\begin{array}{r}1,165 \\
14.70 \%\end{array}$ & $\begin{array}{c}1,337 \\
16.85 \%\end{array}$ & $\begin{array}{r}1,521 \\
19.17 \%\end{array}$ & $\begin{array}{c}1,321 \\
16.65 \% \\
\end{array}$ & $\begin{array}{r}1,129 \\
14.23 \%\end{array}$ & $9.60 \%^{762}$ \\
\hline
\end{tabular}

Table 10: Daily Mortality due to COVID-19 was the lowest on Sundays (10.09.20).

\begin{tabular}{|c|c|c|c|c|c|c|c|c|}
\hline Country: & $\begin{array}{r}\text { Total } \\
+/-\Delta\end{array}$ & Sun & Mon & Tue & Wed & Thu & Fri & Sat \\
\hline 08.03-23.05 & $\begin{aligned} & 32,593 \\
&+ 152 \\
&\end{aligned}$ & $\begin{array}{l}4,035 \\
12.44 \% \\
\end{array}$ & $\begin{array}{c}4,314 \\
13.30 \% \\
\end{array}$ & $\begin{array}{l}4,778 \\
14.73 \% \\
\end{array}$ & $\begin{array}{c}4,678 \\
14.42 \% \\
\end{array}$ & $\begin{array}{r}4,657 \\
14.35 \% \\
\end{array}$ & $\begin{array}{c}4,993 \\
15.39 \% \\
\end{array}$ & $\begin{array}{r}4,986 \\
15.37 \%\end{array}$ \\
\hline 15.03-13.06 & 28,088 & $\begin{array}{c}3,797 \\
13.52 \%\end{array}$ & $\begin{array}{r}3,911 \\
13.92 \%\end{array}$ & $\begin{array}{c}4,003 \\
14.25 \%\end{array}$ & $\begin{array}{r}4,378 \\
15.59 \%\end{array}$ & $\begin{array}{r}4,035 \\
14.37 \%\end{array}$ & $\begin{array}{c}3,986 \\
14.19 \%\end{array}$ & $\begin{array}{r}3,978 \\
14.16 \%\end{array}$ \\
\hline $\begin{array}{l}\text { France } \\
\quad 22.03-16.05\end{array}$ & $\begin{aligned} & 27,039 \\
&- 24 \\
&\end{aligned}$ & $\begin{array}{l}2,324 \\
8.60 \%\end{array}$ & $\begin{array}{r}3,561 \\
13.17 \%\end{array}$ & $\begin{array}{r}4,490 \\
16.61 \%\end{array}$ & $\begin{array}{r}4,046 \\
14.96 \%\end{array}$ & $\begin{array}{c}, 143 \\
19.02 \%\end{array}$ & $\begin{array}{l}4,118 \\
15.23 \%\end{array}$ & $\begin{array}{r}3,357 \\
12.41 \%\end{array}$ \\
\hline $29.03-01.08$ & $\begin{aligned} & 23,451 \\
&+ 4064 \\
&\end{aligned}$ & $\begin{array}{r}3,307 \\
14.10 \%\end{array}$ & $\begin{array}{r}3,298 \\
14.06 \%\end{array}$ & $\begin{array}{r}3,357 \\
14.32 \%\end{array}$ & $\begin{array}{r}3,224 \\
13.75 \%\end{array}$ & $\begin{array}{l}3,464 \\
14.77 \%\end{array}$ & $\begin{array}{c}3,346 \\
14.27 \%\end{array}$ & $\begin{array}{r}3,455 \\
14.73 \%\end{array}$ \\
\hline 01.03-01.08 & $\begin{aligned} & 16,939 \\
- & 37\end{aligned}$ & $\begin{array}{r}2,331 \\
13.76 \%\end{array}$ & $\begin{array}{r}2,421 \\
14.29 \%\end{array}$ & $\begin{array}{l}2,447 \\
14.45 \%\end{array}$ & $\begin{array}{r}2,455 \\
14.49 \%\end{array}$ & $\begin{array}{l}2,531 \\
14.94 \%\end{array}$ & $\begin{array}{l}2,357 \\
13.92 \%\end{array}$ & $\begin{array}{r}2,397 \\
14.15 \%\end{array}$ \\
\hline $\begin{array}{l}\text { South Africa } \\
17.05-01.08\end{array}$ & 7,509 & $9.91 \%^{744}$ & $\begin{array}{r}1,042 \\
13.87 \%\end{array}$ & $\begin{array}{c}1,248 \\
16.62 \%\end{array}$ & $\begin{array}{r}1,020 \\
13.58 \%\end{array}$ & $\begin{array}{l}1,232 \\
16.41 \%\end{array}$ & $\begin{array}{l}1,160 \\
15.45 \%\end{array}$ & $\begin{array}{c}1,063 \\
14.16 \%\end{array}$ \\
\hline
\end{tabular}

Table 11: Daily Mortality due to COVID-19 was the lowest on Mondays (10.09.20).

\begin{tabular}{|c|c|c|c|c|c|c|c|c|}
\hline Country: & $\begin{array}{r}\text { Total } \\
+/-\Delta \\
\end{array}$ & Sun & Mon & Tue & Wed & Thu & Fri & Sat \\
\hline $\begin{array}{r}10.05-01.08 \\
\end{array}$ & $0^{33,641}$ & $\begin{array}{l}4,348 \\
12.92 \% \\
\end{array}$ & $\begin{array}{r}4,197 \\
12.48 \% \\
\end{array}$ & $\begin{array}{r}4,739 \\
14.09 \% \\
\end{array}$ & $\begin{array}{l}5,312 \\
15.79 \% \\
\end{array}$ & $\begin{array}{l}4,911 \\
14.6 \% \\
\end{array}$ & $\begin{array}{l}5,104 \\
15.17 \% \\
\end{array}$ & $\begin{array}{l}5,030 \\
14.95 \% \\
\end{array}$ \\
\hline $\begin{array}{l}\text { Colombia } \\
\qquad 12.04-01.08\end{array}$ & $\begin{array}{lr}10,230 \\
0\end{array}$ & $\begin{array}{l}1,343 \\
13.13 \% \\
\end{array}$ & $\begin{array}{l}1,164 \\
11.38 \% \\
\end{array}$ & $\begin{array}{r}1,356 \\
13.25 \% \\
\end{array}$ & $\begin{array}{l}1,429 \\
13.97 \% \\
\end{array}$ & $\begin{array}{l}1,694 \\
16.56 \% \\
\end{array}$ & $\begin{array}{l}1,698 \\
16.60 \% \\
\end{array}$ & $\begin{array}{l}1,546 \\
15.11 \% \\
\end{array}$ \\
\hline $\begin{array}{l}\text { Belgium } \\
\qquad 22.03-13.06\end{array}$ & $\begin{array}{l}9,412 \\
+365 \\
\end{array}$ & $\begin{array}{l}1,322 \\
14.05 \% \\
\end{array}$ & $\begin{array}{r}1,315 \\
13.97 \% \\
\end{array}$ & $\begin{array}{r}1,376 \\
14.62 \% \\
\end{array}$ & $\begin{array}{l}1,354 \\
14.39 \% \\
\end{array}$ & $\begin{array}{r}1,447 \\
15.37 \% \\
\end{array}$ & $\begin{array}{l}1,278 \\
13.58 \% \\
\end{array}$ & $\begin{array}{c}1,320 \\
14.02 \% \\
\end{array}$ \\
\hline $\begin{array}{ll}\text { Canada } & \\
& 12.04-20.06 \\
\end{array}$ & $0^{7,615}$ & $\begin{array}{r}887 \\
11.65 \% \\
\end{array}$ & $\begin{array}{r}884 \\
11.61 \% \\
\end{array}$ & $\begin{array}{c}1,117 \\
14.67 \% \\
\end{array}$ & $\begin{array}{l}1,158 \\
15.20 \% \\
\end{array}$ & $\begin{array}{c}1,344 \\
17.65 \% \\
\end{array}$ & $\begin{array}{l}1,095 \\
14.38 \% \\
\end{array}$ & $\begin{array}{c}1,130 \\
14.84 \% \\
\end{array}$ \\
\hline $\begin{array}{l}\text { Netherlands } \\
15.03-20.06\end{array}$ & $\begin{aligned} & 5,940 \\
+ & 125\end{aligned}$ & $\begin{array}{c}649 \\
10.93 \%\end{array}$ & $8.28 \%^{492}$ & $\begin{array}{c}1,013 \\
17.05 \%\end{array}$ & $\begin{array}{r}985 \\
16.58 \%\end{array}$ & $\begin{array}{l}969 \\
16.31 \%\end{array}$ & $\begin{array}{r}924 \\
15.56 \%\end{array}$ & $\begin{array}{l}908 \\
15.29 \%\end{array}$ \\
\hline $26.01-14.03$ & 3143 & $\begin{array}{r}497 \\
15.81 \%\end{array}$ & $\begin{array}{r}415 \\
13.21 \%\end{array}$ & $\begin{array}{r}436 \\
13.87 \%\end{array}$ & $\begin{array}{r}442 \\
14.06 \%\end{array}$ & $\begin{array}{l}436 \\
13.87 \%\end{array}$ & $\begin{array}{r}472 \\
15.02 \%\end{array}$ & $\begin{array}{l}445 \\
14.16 \%\end{array}$ \\
\hline
\end{tabular}


Results: For the majority of countries, mortality data for the past months was stable and did not change over time $[\Delta=0]$. Small changes have occurred in database of Netherlands [+125], Italy [+152], the Unites States of America [+284] and Belgium [+365]. Significant changes have been observed in the databases of Peru [+4064] and the United Kingdom [-4925].

Netherlands: The total number of deaths related to the analysed weeks (15.03-20.06) increased from $5,815$ up to 5,940 cases [ $\Delta=+125]$, HLM ratio was increased from 2.04 up to 2.06; but the day with the lowest daily mortality was not changed.

Italy: The total number of deaths related to the analysed weeks (29.03-01.08) increased from 32,441 up to 32,593 cases $[\Delta=+152]$, HLM ratio and the day with the lowest daily mortality was not changed.

The United States of America: The total number of deaths related to the analysed weeks (29.0301.08) increased from 155,115 up to 155,399 cases $[\Delta=+284]$, HLM ratio and the day with the lowest daily mortality were not changed. The comparison of the daily mortality between Sundays and Thursdays revealed increasing significance of the difference from $(p<0.005)$ to $(p<0.001)$.

Belgium: The total number of deaths related to analysed weeks (22.03-13.06) increased from 9,047 cases up to 9,412 cases $[\Delta=+365]$, HLM ratio decreased from 1.48 to 1.13 , and the day with the lowest daily mortality was changed from Monday to Friday.

Peru: The total number of deaths related to the analysed weeks (29.03-01.08) increased from 19,387 up to 23,451 cases [ $\Delta=+4064$ ], HLM ratio was decreased from 1.13 to 1.07 , and the day with the lowest daily mortality was changed from Sunday to Wednesday (Fig. 8).

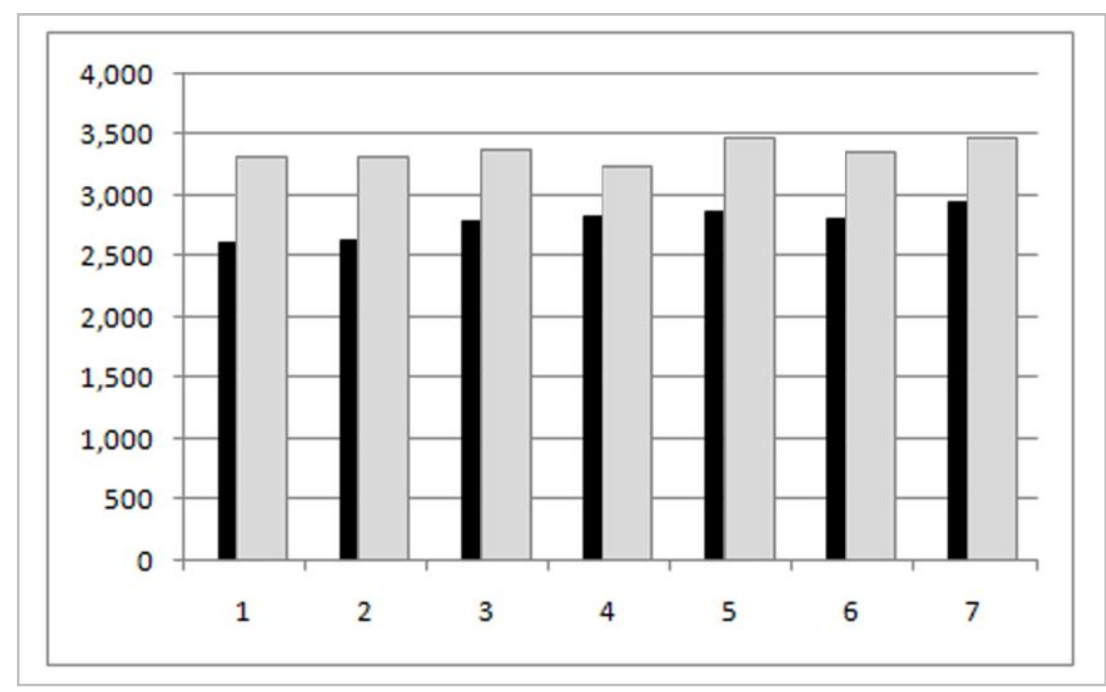

Figure 8. Mortality due to CoViD-19 on Various Days of the Week in the Peru (29.03.20-01.08.20). There are death numbers according to the database collected on August 10 (black) and September 10 (grey). The difference in the total death numbers was $+4064: 1$. Sunday $(+714)$, 2. Monday $(+672)$, 3. Tuesday $(+587)$, 4. Wednesday (+399), 5. Thurs day (+617), 6. Friday $(+551)$, 7. Saturday $(+524)$. 
The United Kingdom: The total number of deaths related to analysed weeks (29.03-01.08) decreased from 44,670 to 39,745 cases [ $\Delta=-4925$ ]. After adjustment HLM was decreased from 2.06 to 2.04 and the difference in the daily mortality between various days of the week became not significant ( $>0.05$ ). Monday remained to be the day with the lowest mortality (Fig. 9).

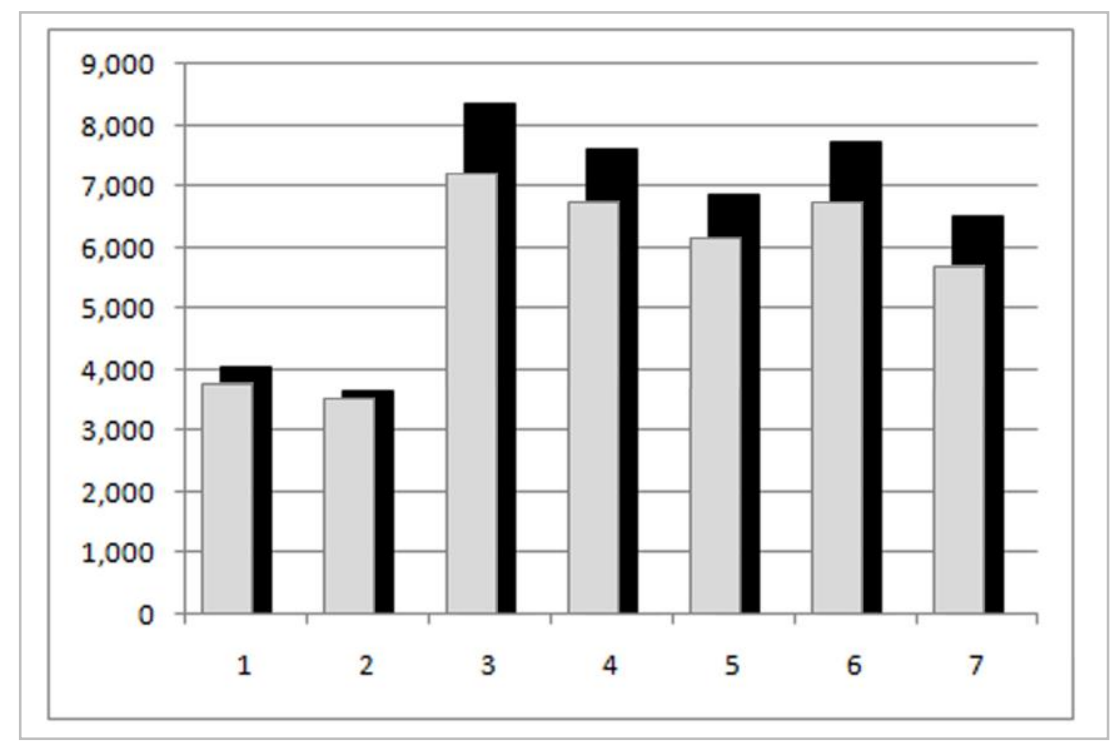

Figure 9. Mortality due to CoViD-19 on Various Days of the Week in the UK (29.03.20-01.08.20). There are death numbers according to the database collected on August 10 (black) and September 10 (grey). The difference in the total death numbers is -4925 : 1. Sunday (-304), 2. Monday $(-122)$, 3. Tuesday $(-1146)$, 4. Wednesday (-853), 5. Thursday (-687), 6. Friday (-997), 7. Saturday (-816).

Argentina: After collection new data on September 10, the weekly mortality cycle was revealed in Argentina. In the analysed 22 weeks (05.04-05.09), on Sundays, the daily mortality was less than on Tuesdays, Wednesdays, Thursdays and Fridays ( $\mathrm{p}<0.05$ ). HLM (Friday/Sunday) was 2.31 .

Remark: Further monitoring (10.09-20.09.20) of the database related to the countries analysed before, revealed them to be stable $[\Delta=0]$, excluding database of the United States of America that was replenished with the new 55 cases.

Conclusion: For patients suffering from CoViD-19, the safest days of the week were mostly Sundays or Mondays. Updating and correction of global and local mortality data didn't affect Weekly Mortality Cycle in general, but affected this cycle in certain countries, including Argentina, Belgium, Peru and the United Kingdom.

\section{A Weekly Cycle relates to the Human Civilization.}

In the 18th century, Antoine-Yves Goguet wrote: "We can consider as the first step that men have taken to obtain a measure of time, was the establishment of the small period of seven days, 
which bears the name of the week. We see that, from time immemorial, it has been used by almost all peoples, and that the arrangement has been perfectly uniform". ${ }^{21}$

Our contemporary, Joseph Needham, expressed a modern view on the calendar and said, that some of its elements are based on those astronomical cycles which have obvious importance for man, such as the day, the month and the year; others are artificial, such as the week and the subdivisions of the day. ${ }^{22}$ Eviatar Zerubavel, describing the characteristics of the weekly cycle, titled his book "Hidden Rhythms". ${ }^{23}$

\section{Discussion.}

On the one hand, a week as a time frame obviously exists, but on the other, there is no natural basis that could explain a weekly cycle.

As described above the weekly mortality cycle with the trend towards decreased mortality on weekends is a unique phenomenon that has been observed among victims of CoViD-19. It has an opposite pattern compared to increased hospital mortality on weekends in the United Kingdom discussed in $2015 .^{24}$

\section{Conclusion.}

It is vitally important to recognize factors which formed the basis of decreased mortality on Sundays, Mondays and some other "safest days" of the week. These factors can relate to various aspects of healthcare, including therapeutic protocols and work schedules, or to human habits and traditions. Presumably, they relate to the optimised therapeutic protocols used on the "safest days".

If the factors, which reduced mortality on certain days of the week, could be identified, their positive effect should be spread to other days of the week. As a result many lives of CoViD-19 patients could be saved in future.

\section{Acknowledgment:}

I am grateful to my colleagues from Brazil, China, Italy, Malaysia, and the USA who shared with me therapeutic protocols used at their hospitals for CoViD-19 patients.

\section{Disclosure Statement:}

The author declares there are no any conflicts of interest in the submitted manuscripts.

\section{Final Remark:}

The first study on the Weekly Mortality Cycle among CoViD-19 patients was completed on Aug 1, the second one was completed on Aug. 14, the last study was completed on Sep 21, 2020.

A manuscript of the second study was sent to my colleagues living in different countries. From that time they began their own investigations on their places. 


\section{References:}

1. Liu YC, Kuo RL, Shih SR. COVID-19: The first documented coronavirus pandemic in history. Biomed J. 2020;S2319-4170(20)30044-5. doi: 10.1016/j.bj.2020.04.007 [Epub ahead of print].

2. Google Search for "CoViD-19". [cited 2020 Sep 21]. Available from: https://www.google.com/search?client=firefox-b-d\&q=\%22CoViD-19\%22

3. Li Q, Guan XH, Wu P. et al. Early Transmission Dynamics in Wuhan, China, of Novel Coronavirus - Infected Pneumonia. N Engl J Med 2020; 382(13): 1199-07.

4. Lucey D, Kent K. Coronavirus - Unknown Source, Unrecognized Spread, and Pandemic Potential. - Think Global Health, Feb 6, 2020. [cited 2020 Aug 10]. Available from: https://www.thinkglobalhealth.org/article/coronavirus-unknown-source-unrecognized-spread-andpandemic-potential

5. Nesteruk I. Waves of COVID-19 pandemic. Detection and SIR simulations. - medRxiv, Posted August 04, 2020. doi: https://doi.org/10.1101/2020.08.03.20167098.

6. Worldometers: Coronavirus Worldwide Graphs [cited 2020, Jul 6-...-Sep 20]. Available from: https:/www.worldometers.info/coronavirus/worldwide-graphs/

7. Imai N, Dorigatti I, Cori A, et al. Report 1 - Estimating the potential total number of novel Coronavirus cases in Wuhan City, China - January 17, 2020. https $/ / w w w . i m p e r i a l . a c . u k / m r c-$ global-infectious-disease-analysis/covid-19/report-1-case-estimates-of-covid-19/

8. Imai N, Dorigatti I, Cori A, et al. Report 2 - Estimating the potential total number of novel Coronavirus (2019-nCoV) cases in Wuhan City, China. - January 22, 2020:

https:/www.imperial.ac.uk/mrc-global-infectious-d isease-analys is/covid-19/report-2-update-caseestimates-covid-19/

9. Salje H, Kiem CT, Lefrancq N. et al. Estimating the burden of SARS-CoV-2 in France. Science; 2020, 369(6500): 208-11; DOI: 10.1126/science.abc3517

10. Fenton N, Osman M, Neil M, McLachlan S. Study suggests more people have had coronavirus than previously estimated. - Medicalxpress, June 26, 2020. [cited 2020 Aug 10]. Available from: https://medicalxpress.com/news/2020-06-people-coronavirus-previously.html

11. Brown, R. (2020). Public health lessons learned from biases in coronavirus mortality overestimation. Disaster Med Public Health Prep, 1-24. doi:10.1017/dmp.2020.298

12. Worldometers: Reported Cases and Deaths by Country, Territory, or Conveyance. [cited 2020, Jul 6- .. - Sep 20]. Available from: https://www. worldometers.info/coronavirus/\#countries

13. Ricon-Becker I, Tarrasch R, Blinder P, Ben-Eliyahu S. A seven-day cycle in COVID-19 infection and mortality rates: Are inter-generational social interactions on the weekends killing susceptible people? - medRxiv, May 08, 2020 doi: https://doi.org/10.1101/2020.05.03.20089508 
14. Worldometers: Reported Cases and Deaths by Country, Territory, or Conveyance: United States

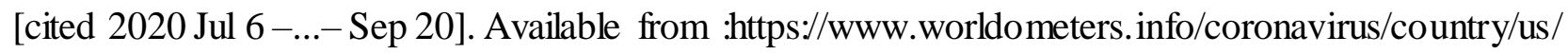

15. Worldometers: Reported Cases and Deaths by Country, Territory, or Conveyance: China [cited 2020 Aug 20]. Available from: https:/www.worldometers.info/coronavirus/country/china/

16. Chinese mainland reports 82,692 overall confirmed COVID-19 cases as Wuhan revises figures: official. - Xinhua, April 17, 2020. [cited 2020 Aug 10]. Available from: http $/ /$ en.people.cn/n3/2020/0417/c90000-9681219.html

17. Shah M. Canada approaches $91 \mathrm{~K}$ coronavirus cases; sharp rise in daily deaths due to glitch. Global News, May 31, 2020. [cited 2020 Aug 10]. Available from: https:/globalnews.ca/news/7009672/canada-coronavirus-cases-may-31/

18. Natalia A. Ramos Miranda. Chile Coronavirus Death Toll Jumps Sharply After New Cases Added. - U.S. News, June 7, 2020. [cited 2020 Aug 10]. Available from: https://www.usnews.com/news/world/articles/2020-06-07/chile-coronavirus-death-toll-jumpssharply-after-new-cases-added

19. The Latest: India adds over 2,000 deaths as new cases soar. - CityNews (The Associated Press, Jun 16, 2020. [cited 2020 Aug 10]. Available from: https:/www.660citynews.com/2020/06/16/the-latest-ind ia-adds-over-2000-deaths-as-new-cases-soar/

20. France revises COVID-19 toll slightly downwards to 28,022. - Reuters, May 20, 2020. [cited 2020 Aug 10]. Available from: https://www.reuters.com/article/health-coronavirus-francecasualties/france-revises-covid-19-toll-slightly-downwards-to-28022-idUSP6N2BQ03Y

21. Goguet A.-Y. De L'Origine des Loix, des Arts, et des Sciences: et de leurs progrès chez les anciens peuples. T 1. - La Haye: Pierre Gosse Junior, 1758: 474-475. (https://catalog.hathitrust.org/Record/008640994)

22. Needham J. Calendrical and Planetary Astronomy. - In: Needham J, Ling W. Science and Civilization in China. Vol. 3: Mathematics and the Sciences of the Heavens and the Earth. Cambridge: Cambridge University Press, 1959: 390-408.

(https://books.google.com.my/books?id=jfQ9E0u4pLAC\&source=gbs_navlinks_s)

23. Zerubavel E. Hidden Rhythms: Schedules and Calendars in Social Life. - Berkeley: University of California Press, 1985. (https $/ /$ archive.org/details/hiddenrhythmssch0000zeru) 24. Aylin P. Making sense of the evidence for the "weekend effect". - BMJ, 2015, Sep 5; 351:h4652. DOI: 10.1136/bmj.h4652 